\title{
Responses to simulated nitrogen deposition by the neotropical epiphytic orchid Laelia speciosa
}

Edison A. Díaz-Álvarez, Roberto Lindig-Cisneros, Erick de la Barrera

Potential ecophysiological responses to nitrogen deposition, which is considered to be one of the leading causes for global biodiversity loss, were studied for the endangered endemic Mexican epiphytic orchid, Laelia speciosa, via a shadehouse dose-response experiment (doses were $2.5,5,10,20,40$, and $80 \mathrm{~kg} \mathrm{~N} \mathrm{ha}^{-1} \mathrm{yr}^{-1}$ ) in order to assess the potential risk facing this orchid given impending scenarios of nitrogen deposition. Lower doses of nitrogen of up to $20 \mathrm{~kg} \mathrm{~N}$ ha $\mathrm{yr}^{-1}$, the dose that led to optimal plant performance, acted as fertilizer. For instance, the production of leaves and pseudobulbs were respectively $35 \%$ and $36 \%$ greater for plants receiving $20 \mathrm{~kg} \mathrm{~N}$ ha $\mathrm{yr}^{-1}$ than under any other dose. Also, the chlorophyll content and quantum yield peaked at $0.66 \pm 0.03 \mathrm{~g} \mathrm{~m}^{-2}$ and $0.85 \pm 0.01$, respectively, for plants growing under the optimum dose. In contrast, toxic effects were observed at the higher doses of 40 and $80 \mathrm{~kg} \mathrm{~N}$ ha $\mathrm{yr}^{-1}$. The $\delta^{13} \mathrm{C}$ for leaves averaged -14.7 $\pm 0.2 \%$ regardless of the nitrogen dose. In turn, $\delta^{15} \mathrm{~N}$ decreased as the nitrogen dose increased from $0.9 \pm 0.1 \%$ under $2.5 \mathrm{~kg} \mathrm{~N} \mathrm{ha}^{-1} \mathrm{yr}^{-1}$ to $-3.1 \pm 0.2 \%$ under $80 \mathrm{~kg} \mathrm{~N} \mathrm{ha}^{-1} \mathrm{yr}^{-1}$, indicating that orchids preferentially assimilate $\mathrm{NH}_{4}{ }^{+}$rather than $\mathrm{NO}_{3}{ }^{-}$of the solution under higher doses of nitrogen. Laelia speciosa showed a clear response to inputs of nitrogen, thus, increasing rates of atmospheric nitrogen deposition can pose an important threat for this species. 
2 10 Universitaria, México, Distrito Federal 04510, Mexico

11

12 bInstituto de Investigaciones en Ecosistemas y Sustentabilidad, Universidad Nacional

13 Autónoma de México, Morelia, Michoacán 58190, Mexico.

\section{Responses to simulated nitrogen deposition by the neotropical epiphytic orchid Laelia} speciosa

.

(1)

\author{
Edison A. Díaz-Álvarez ${ }^{\mathrm{a}, \mathrm{b}}$, Roberto Lindig-Cisneros ${ }^{\mathrm{b}}$, \\ and Erick de la Barrera ${ }^{b, *}$
}

aPosgrado en Ciencias Biológicas, Universidad Nacional Autónoma de México, Ciudad

14

5

6

\footnotetext{
*Correspondence: Erick de la Barrera, tel.: + 52 (443) 3223810, fax +52 (443) 3222719, email: delabarrera@unam.mx
}

8

.

20

21

22




\section{ABSTRACT}

Potential ecophysiological responses to nitrogen deposition, which is considered to be one of the leading causes for global biodiversity loss, were studied for the endangered endemic Mexican epiphytic orchid, Laelia speciosa, via a shadehouse dose-response experiment (doses were $2.5,5,10,20,40$, and $80 \mathrm{~kg} \mathrm{~N} \mathrm{ha}^{-1} \mathrm{yr}^{-1}$ ) in order to assess the potential risk facing this orchid given impending scenarios of nitrogen deposition. Lower doses of nitrogen of up to 20 $\mathrm{kg} \mathrm{N}$ ha $\mathrm{yr}^{-1}$, the dose that led to optimal plant performance, acted as fertilizer. For instance, the production of leaves and pseudobulbs were respectively $35 \%$ and $36 \%$ greater for plants

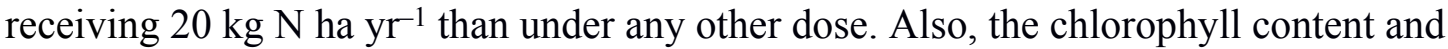
quantum yield peaked at $0.66 \pm 0.03 \mathrm{~g} \mathrm{~m}^{-2}$ and $0.85 \pm 0.01$, respectively, for plants growing under the optimum dose. In contrast, toxic effects were observed at the higher doses of 40 and $80 \mathrm{~kg} \mathrm{~N}$ ha $\mathrm{yr}^{-1}$. The $\delta^{13} \mathrm{C}$ for leaves averaged $-14.7 \pm 0.2 \%$ regardless of the nitrogen dose. In turn, $\delta^{15} \mathrm{~N}$ decreased as the nitrogen dose increased from $0.9 \pm 0.1 \%$ under $2.5 \mathrm{~kg} \mathrm{~N} \mathrm{ha}^{-1} \mathrm{yr}^{-1}$ to $-3.1 \pm 0.2 \%$ under $80 \mathrm{~kg} \mathrm{~N} \mathrm{ha}^{-1} \mathrm{yr}^{-1}$, indicating that orchids preferentially assimilate $\mathrm{NH}_{4}^{+}$ rather than $\mathrm{NO}_{3}^{-}$of the solution under higher doses of nitrogen. Laelia speciosa showed a clear response to inputs of nitrogen, thus, increasing rates of atmospheric nitrogen deposition can pose an important threat for this species.

Key words: biodiversity loss; CAM; conservation physiology; $\delta^{15} \mathrm{~N}$; nitrogen pollution; stable isotopes. 


\section{INTRODUCTION}

Anthropogenic atmospheric nitrogen deposition is considered among the leading global causes of biodiversity loss (Vitousek, 1994; Chapin et al., 2000; Sala et al., 2000). While nitrogen is an essential nutrient for all living organisms, its accelerated release to the atmosphere and ultimate deposition has caused saturation of various ecosystems around the world, leading to significant biodiversity loss by direct toxicity, acidification, and nutrient imbalances between nitrogen and other major nutrients (Aber et al., 1989; Bauer et al., 2004; Le Bauer and Treseder, 2008; Bobbink et al., 2010; Templer et al., 2012). Most studies regarding the effects of nitrogen deposition on biodiversity have been conducted in the USA and Europe, while studies from megadiverse countries are scant (Bobbink et al., 2010). Considering that the latter countries tend to have developing economies and accelerated industrialization processes, it is urgent to determine the effects that current and future nitrogen deposition rates may have on their local biodiversities (Austin et al., 2013).

A life-form particularly susceptible to the noxious effects of nitrogen deposition are epiphytic plants, such as certain species of orchids and bromeliads, given their reliance on atmospheric sources for nutrients and water (Zotz and Asshoff, 2010; Zotz et al., 2010; Mondragón et al., 2015). In this respect, Laelia speciosa (Kunth.) Shltr. (Orchidaceae) is an endemic, endangered orchid from central Mexico that has a cultural importance in Michoacán. Not only the plant is collected for its attractive flowers, but juice is extracted from its pseudobulbs and mixed with maize cane pith to produce a paste that is used for the production of sacred art in West Central Mexico (Soto-Arenas and Solano-Gómez, 2007). In addition to extractive pressure, this species faces environmental challenges considering that oak forests, to which this species is restricted, are likely to be severely reduced during the 
present century (Villers-Ruiz and Trejo-Vázquez, 2000; Rehfeldt et al., 2012). This study assessed whether nitrogen deposition can also pose a threat to this species. However, because current rates of nitrogen deposition are rather low within the area of distribution for $L$. speciosa (Díaz-Álvarez et al., 2014), it was deemed necessary to conduct a shadehouse doseresponse experiment to determine the effects of potential future nitrogen deposition on this plant.

Indeed, the purpose of this study was to determine some ecophysiological responses of the endangered neotropical epiphytic orchid Laelia speciosa by means of a dose-response shadehouse experiment, in which, the organ production, chlorophyll content, chlorophyll fluorescence, carbon and nitrogen content and isotopic signatures were evaluated for assessing the potential risk that increasing rates of nitrogen deposition pose for this species.

\section{MATERIALS AND METHODS}

Plant material

Laelia speciosa is a sympodial epiphytic orchid with big and showy flowers that have pink to lilac-purple petals and a white lip. Flowers are produced during the spring, while an annually produced carbon-storing pseudobulb develops during the summer. Laelia speciosa grows in sub-humid temperate climates of central Mexico, between 1250 and $2500 \mathrm{~m}$ where its predominant phorophyte Quercus deserticola is also found (Soto-Arenas and SolanoGómez, 2007).

Two-year old plants of Laelia speciosa obtained by in vitro propagation were transferred into $2 \mathrm{~L}$ plastic pots containing tezontle (particles were $2-5 \mathrm{~cm}$ in diameter), a very porous volcanic rock that is extensively utilized for gardening and hydroponic horticulture given its 
96

97

98

99

100

101

102

103

104

105

106

107

108

109

110

111

112

113

114

115

116

117

118

suitable physicochemical properties (Vargas-Tapia et al., 2008; Yáñez-Ocampo et al., 2009).

Organic matter was removed from the tezontle by submersion in a $\mathrm{SO}_{4} \mathrm{H}_{2}$ aqueous solution $(50 \% \mathrm{v} / \mathrm{v})$ followed by a double rinse with deionized, distilled water. The procedure was repeated thrice. The pots were placed in a shadehouse for 2 years at Universidad Nacional Autónoma de México, Campus Morelia (19³8' 55.9” N; 101 13’ 45” W; 1967m, mean annual temperature of $18.3{ }^{\circ} \mathrm{C}$, annual precipitation $773 \mathrm{~mm}$; Servicio Meteorológico Nacional, 2011), where they were watered every other week until the start of the experiment. A total of 120 plants were selected at random and assigned to one of six groups, each with 20 plants, which received different doses of nitrogen. At the start of the experiment, the plants had 4 pseudobulbs and one leaf $(15 \mathrm{~cm}$ in length).

\section{Nitrogen deposition scenarios}

Starting on 1 October 2011, the plants were watered weekly over two months with $50 \mathrm{ml}$ of a modified Hoagland No. 2 solution from which the nitrogen was omitted to be able to simultaneously supply suitable amounts of nutrients and manipulate the dose of nitrogen dispensed to plants (Hoaglan and Arnon, 1950; Nobel and de la Barrera, 2002). At the end of this period, six simulated atmospheric deposition scenarios were applied by adding 1, 4, 8, 16, $32 \mathrm{mM}$ of $\mathrm{NH}_{4} \mathrm{NO}_{3}$ to the watering solution, equivalent to $2.5,10,20,40$, or $80 \mathrm{~kg}$ of $\mathrm{N} \mathrm{ha}^{-1}$ $\mathrm{yr}^{-1}$ respectively. In this respect, a threshold for plant physiological damage has been observed at $20 \mathrm{~kg} \mathrm{~N} \mathrm{ha}^{-1} \mathrm{yr}^{-1}$, while rates of $40 \mathrm{~kg} \mathrm{~N} \mathrm{ha}^{-1} \mathrm{yr}^{-1}$ are common in certain parts of Mexico City (Britto and Kronzucker 2002; Secretaría del Medio Ambiente del Gobierno del Distrito Federal 2012). The range of doses considered was chosen to establish the threshold for physiological damage for L. speciosa, and to determine the effects of deposition rates that are 
119 likely to occur during the present century. All amounts were calculated according to the area

120 of the pot of $201 \mathrm{~cm}^{2}$. Weekly applications of $50 \mathrm{ml}$ of the experimental solutions were

121 conducted over 26 weeks, from December 2011 to June 2012. This period corresponds to the

122 growth season and reproductive development of Laelia speciosa (Halbinger and Soto-Arenas,

123 1997; Soto-Arenas, 1994; Soto-Arenas and Solano-Gómez, 2007). Irrigation was carried out

124 on the whole surface of the pot, the coarse substrate allowed the complete drainage of the

125 nutrient solution, simulating what occurs in the canopy.

126

127 Physiological responses

$128 \quad \underline{\text { Organ production }}$

129 The emergence of flowers, which are displayed for a few weeks, was recorded weekly. In

130 turn, the total production of new leaves and pseudobulbs, which are persistent, was recorded

131 at the end of the experiment.

132

133 Chlorophyll content

134 Leaf discs were obtained with a cork borer (12-mm in diameter) from 5 plants per

135 nitrogen deposition scenario to determine the concentration of chlorophyll a, chlorophyll b,

136 and total chlorophyll in the plant tissue. The photosynthetic pigments were extracted by

137 macerating leaf tissue with a chilled $\left(3^{\circ} \mathrm{C}\right)$ mortar and pestle in an aqueous solution of

138 acetone $(80 \% \mathrm{v} / \mathrm{v})$ and brought to a final volume of $20 \mathrm{ml}$. Absorbance was measured at 663

139 and $646 \mathrm{~nm}$ with an EZ 301 spectrophotometer (Perkin Elmer, Waltham, Massachusetts,

140 USA). Chlorophyll concentration was calculated following Lichtenthaler (1987).

141 
142

143

144

145

146

147

148

149

150

151

152

153

154

155

156

157

158

159

160

161

162

163

\section{Chlorophyll fluorescence (Fv/Fm)}

The maximum yield of the photosystem II (the ratio of variable to maximum fluorescence; Fv/Fm) was measured with an Opti-Science 05-30p Fluorometer (Hudson, New Hampshire, USA). Measurements were carried out before dawn, a common practice in plant ecophysiology (Maxwell and Johnson, 2000), for the leaves of five individuals per dose of nitrogen on 29 June and 2 July 2012.

\section{$\underline{\text { Carbon and nitrogen content and isotopic composition }}$}

The leaves of plants growing under different nitrogen doses were collected on 4 July 2012 and dried at $80{ }^{\circ} \mathrm{C}$ in a gravity convection oven until reaching constant weight. This temperature has been found to be adequate for tropical succulents, whose membrane proteins can withstand temperatures that are substantially higher than for non-succulent species without incurring in damage (Nobel and de la Barrera, 2002; Drennan, 2009). The dried leaves were ground to a fine powder in a ball mill (Retsch MM300; Retsch, Vienna, Austria), wrapped into tin capsules (Costech Analytical, Inc. Valencia, California, USA), and weighed with a microbalance $(0.01 \mathrm{mg}$, Sartorius, Göttingen, Germany). For each sample, the carbon and nitrogen content, as well as their isotopic proportions, were determined at the Stable Isotope Facility, University of Wyoming (Laramie, Wyoming, USA), with a Carlo Erba EA 1110 elemental analyzer (Costech Analytical Inc., Valencia, CA, USA) attached to a continuous flow isotope ratio mass spectrometer (Finnigan Delta Plus XP, Thermo Electron Corp, Waltham, MA). Carbon and nitrogen isotope ratios, reported in parts per thousand, were calculated relative to the Vienna Pee Dee Belemnite (V-PDB) or atmospheric air 
164 standards, respectively. The analytical precision for $\delta^{13} \mathrm{C}$ was $\pm 0.03 \%$ (SD) and $\pm 0.06 \%$ (SD)

165 for $\delta^{15} \mathrm{~N}$. The natural abundances of ${ }^{13} \mathrm{C}$ and ${ }^{15} \mathrm{~N}$ were calculated as:

166

167

168

169

170

171

172

173

174

175

176

177

178

179

180

181

182

183

184

185

186

\section{Statistical analyses}

The effect of the simulated nitrogen deposition on organ production for Laelia speciosa was evaluated by means of a Kruskal-Wallis non-parametric ANOVA, because normality of data was not satisfied, followed by post-hoc Tukey tests $(P \leq 0.05)$. In turn, differences in the response of chlorophyll content, chlorophyll fluorescence, carbon and nitrogen content, and $\delta^{13} \mathrm{C}$ and $\delta^{15} \mathrm{~N}$, which achieved normality, were evaluated with a one-way ANOVA followed by the Holm-Sidak post-hoc test $(P \leq 0.05)$. All analyses were conducted on SigmaPlot 12 (Systat Software Inc. USA).

\section{RESULTS}

\section{Organ production}

After 26 weeks of watering the plants with different doses of nitrogen, the production of new organs was greater for those individuals that received $20 \mathrm{~kg} \mathrm{~N} \mathrm{ha}^{-1} \mathrm{yr}^{-1}$ than for those individuals receiving other nitrogen doses (Table 1; Fig. 1). In particular, $1.0 \pm 0.1$ leaves were produced per plant over the course of the experiment under most doses, except for the plants that received $20 \mathrm{~kg} \mathrm{~N} \mathrm{ha}^{-1} \mathrm{yr}^{-1}$, which produced $35 \%$ more leaves $(P \leq 0.001)$. Similar 
187 was the case for the $0.9 \pm 0.1$ pseudobulbs produced per plant under most doses, except for

188 the plants that received $20 \mathrm{~kg} \mathrm{~N} \mathrm{ha}^{-1} \mathrm{yr}^{-1}$, which produced $36 \%$ more pseudobulbs $(P \leq 0.001)$.

189 In contrast, flowering was not significantly influenced by nitrogen dose $(\mathrm{P}=0.077)$, with a

190 production of $0.3 \pm 0.04$ flowers per plant over the course of the experiment (Table 1; Fig. 1).

\section{Chlorophyll fluorescence}

The quantum efficiency of photosystem II (Fv/Fm) was similar among the groups of

194 orchids that received up to $20 \mathrm{~kg} \mathrm{~N} \mathrm{ha}^{-1} \mathrm{yr}^{-1}$ amounting to 0.8 , while a significant decrease of

$19523 \%$ was observed for plants irrigated with higher concentrations of nitrogen $(P \leq 0.001$;

196 Table 1; Fig 2A).

197

$198 \quad$ Chlorophyll content

199 Total chlorophyll content for the leaf tissue of Laelia speciosa increased as the nitrogen

200 dose increased, peaking at $0.7 \pm 0.0 \mathrm{~g} \mathrm{~m}^{-2}$ for plants irrigated with $20 \mathrm{~kg} \mathrm{~N} \mathrm{ha}^{-1} \mathrm{yr}^{-1}(P \leq$

201 0.001; Table 1; Fig 2B), while the higher doses of nitrogen resulted in a $38 \%$ reduction of the

202 pigment. Similarly, the chlorophyll a concentration of $0.5 \pm 0.4 \mathrm{~g} \mathrm{~m}^{-2}$ was the maximum for

203 plants growing under $20 \mathrm{~kg} \mathrm{~N} \mathrm{ha}^{-1} \mathrm{yr}^{-1}$, and it was $30 \%$ lower under all other nitrogen doses $(P$

$204 \leq 0.001)$. In turn, chlorophyll $\mathrm{b}$ did not respond to nitrogen, averaging $0.1 \pm 0.0 \mathrm{~g} \mathrm{~m}^{-2}$

205 regardless of the dose under which plants grew (Table 1; Fig 2B).

206

207

Carbon and nitrogen content and isotopic composition 
The carbon content of Laelia speciosa increased with the nitrogen dose peaking at $46.1 \pm$ $0.3 \%$ (dry mass basis) at 20 and $40 \mathrm{~kg} \mathrm{~N} \mathrm{ha}^{-1} \mathrm{yr}^{-1}$ and decreased to $45.2 \pm 0.3 \%$ at $80 \mathrm{~kg} \mathrm{~N}$ ha${ }^{1} \mathrm{yr}^{-1}(P \leq 0.001$; Table 1; Fig. 2C).

The nitrogen content for Laelia speciosa also increased with the nitrogen dose. For the plants that received up to $10 \mathrm{~kg} \mathrm{~N} \mathrm{ha}^{-1} \mathrm{yr}^{-1}$ the nitrogen content averaged $1.2 \pm 0.0 \%$ (dry mass basis), reaching $2.4 \pm 0.0 \%$ at $80 \mathrm{~kg} \mathrm{~N} \mathrm{ha}^{-1} \mathrm{yr}^{-1}(P \leq 0.001$; Table 1; Fig. 2D).

The $\delta^{13} \mathrm{C}$ for leaves of Laelia speciosa averaged $-14.7 \pm 0.2 \%$ and did not change with the nitrogen dose $(P=0.057$; Table 1$)$. In contrast, the leaf $\delta^{15} \mathrm{~N}$ significantly decreased at higher nitrogen doses. The $\delta^{15} \mathrm{~N}$ averaged $0.9 \pm 0.1 \%$ for plants that received up to $10 \mathrm{~kg} \mathrm{~N} \mathrm{ha}{ }^{-}$ ${ }^{1} \mathrm{yr}^{-1}$, a $\delta^{15} \mathrm{~N}$ similar to the $\delta^{15} \mathrm{~N}$ of $1.1 \pm 0.1 \%$ measured for the $\mathrm{NH}_{4} \mathrm{NO}_{3}$ utilized for the nutrient solution. The higher doses of nitrogen led to significant decreases of $\delta^{15} \mathrm{~N}$, reaching the minimum of $-3.1 \pm 0.2 \%$ for plants growing under $80 \mathrm{~kg} \mathrm{~N} \mathrm{ha}^{-1} \mathrm{yr}^{-1}(P \leq 0.001$; Table 1 ; Fig. 2E)

\section{DISCUSSION}

An intermediate nitrogen dose of $20 \mathrm{~kg} \mathrm{~N} \mathrm{ha}^{-1} \mathrm{yr}^{-1}$ was the most favorable for the production of new organs by Laelia speciosa. Lower doses did not improve plant development substantially but higher doses where inhibiting. In this respect, while nitrogen availability may increase leaf production and growth, large quantities of nitrogen limit the availability of other nutrients, restricting the plant's ability to produce foliar mass (Evans, 1989; Asner et al., 1997; Aber et al., 1998; Sánchez et al., 2000; Zotz and Asshoff, 2010; Díaz-Álvarez et al., 2014). Such behavior was observed for Laelia speciosa that showed a substantial reduction in the production of new organs, suggesting noxious effects of the 
232 increased pseudobulb production (Barman et al., 2004). In turn, pseudobulb growth for

233 Dendrobium nobile peaks at nitrogen doses of $1.9 \mathrm{mM}$ (Bichsel et al., 2008).

234 Total chlorophyll content is proportional to the content of nitrogen in leaves, which

235 typically ranges between 0.4 and $0.5 \mathrm{~g} \mathrm{~m}^{-2}$ (Evans, 1989; Nobel, 1999; Nobel and de la

236 Barrera, 2002). Indeed, for Laelia speciosa, chlorophyll content increased with the dose of

237 nitrogen, suggesting that this plant was able to assimilate and utilize the supplied nitrogen for

238 the production of photosynthetic pigments. However, the higher doses also resulted in a

239 drastic decrease of the chlorophyll content, as has been documented for other plant species

240 (Baxter et al., 1992; Majerowicz et al., 2000; Lin et al., 2007; Arróniz-Crespo et al., 2008;

241 Ying-Chun et al., 2010). Such a decrease in the chlorophyll content can be explained by the

242 resulting imbalance of the nitrogen to magnesium ratio in the leaf (Nakaji et al., 2001;

243 Wortman et al., 2012). Excessive nitrogen in the cell promotes release of protons $\left(\mathrm{H}^{+}\right)$and

244 accumulation of phenolic compounds and hydrogen peroxide, as a result, the $\mathrm{pH}$ can be

245 altered impeding chlorophyll production and loss of $\mathrm{Mg}^{2+}$ (Mangosá and Berger, 1997;

246 Sánchez et al., 2000; Britto and Konzucker, 2002). Changes in chlorophyll content for Laelia

247 speciosa were accompanied by changes in the efficiency of photosystem II, which can be

248 attributed to oxidative stress in the thylakoids that results in the blockage of electron transport

249 to the oxidation site, as a consequence of low available energy for photosynthesis (Maxwell

250 and Johnson, 2000; Poorter, 2000; Hogewoning and Harbinson, 2007; Lichtenthaler et al.,

251 2007; Baker, 2008; Calatayud et al., 2008; Guidi and Degl'Innocenti, 2008; Massacci et al., 252 2008).

253

Plants tend to increase their rates of carbon fixation when nitrogen is added (Brown et al., 1996; Bauer et al., 2004; Le Bauer and Treseder, 2008). However, under conditions of chronic 
255 nitrogen additions the photosynthetic capacity is inhibited because most of the excess nitrogen

256 is not invested into the primary processes of carboxylation (Brown et al., 1996; Bauer et al.,

257 2004). This also causes an increase and later reduction in carbon content for plants subjected

258 to increasing doses of nitrogen, as was observed here for Laelia speciosa. However, the

259 observed $\delta^{13} \mathrm{C}$ values for Laelia speciosa which were within the range for CAM plants, did

260 not change under the different nitrogen doses utilized, contrasting with $\delta^{13} \mathrm{C}$ measured for $\mathrm{C}_{3}$

261 plants subjected to supplementary nitrogen that became increasingly negative (Raven and

262 Farquhar, 1990; Magalhaes et al., 1992).

263 Isotopic discrimination against ${ }^{15} \mathrm{~N}$ increases in plants as the nitrogen availability

264 increases because its assimilation is more energetically costly than for the more abundant ${ }^{14} \mathrm{~N}$.

265 This so called isotopic effect results in $\delta^{15} \mathrm{~N}$ values of the product that are lower than those of

266 the substrate (Evans, 2001; Kolb and Evans, 2003; Ariz et al., 2011). The observed

267 discrimination against ${ }^{15} \mathrm{~N}$ for Laelia speciosa leaves has also been observed for various

268 species, such as Oryza sativa, Pinus sylvestris, and Trapa japonica, species that discriminate

269 between 0.9 and $13 \%$ when supplied with increasing doses of nitrogen in form of $\mathrm{NH}_{4}{ }^{+}$

270 (Yoneyama et al., 1991; Högberg et al., 1999; Yoneyama eta al., 2001; Maniruzzaman and

271 Asaeda, 2012). When the nitrogen source is $\mathrm{NH}_{4}{ }^{+}$, this compound is directly assimilated by

272 the plant cell as amino acids and the involved enzyme, glutamine-synthetase, can discriminate

273 up to $17 \%$. On the contrary, plants watered with $\mathrm{NO}_{3}{ }^{-}$have positive $\delta^{15} \mathrm{~N}$ values that have

274 been associated with nitrogen lost via root efflux and exudates or loss of $\mathrm{NH}_{3}$ through the

275 stomata, processes that favor the lighter isotope (O'Deen 1989; Yoneyama et al., 2001; Ariz

276 et al., 2011). 
Laelia speciosa showed a clear response to increasing doses of nitrogen. Doses of up to $20 \mathrm{Kg} \mathrm{N} \mathrm{ha}^{-1}$ year-1 $^{-1}$ enhanced its physiological performance, while higher doses were toxic. The rates of nitrogen deposition in México, where Laelia speciosa is endemic, could exceed $25 \mathrm{Kg} \mathrm{N} \mathrm{ha}^{-1}$ year${ }^{-1}$ by mid-century (Galloway et al., 2004; Phoenix et al., 2006; Galloway et al., 2008). As a result, nitrogen deposition poses an actual threat for the persistence of this endangered species as other components of global change represent for many other epiphytic vascular plants (Zotz et al., 2010b; Mondragón et al., 2015). Future works should consider the effects of nitrogen deposition on wild populations of this and other tropical epiphytic plants. A better understanding of the effects of increasing nitrogen deposition from human activities is of urgent importance, as species ecophysiological response, as those studied here, may be affected, with potentially negative consequences in ecosystem biodiversity and function.

\section{ACKNOWLEDGEMENTS}

We thank Dr. I Ávila Díaz for providing the plants utilized in this study; the personnel of the IIES Botanical Gardens for maintenance of the plants before the experiment, especially Ms. M.D. Lugo and Mr. J. Martinez Cruz; and Dr. D.G. Williams at the University of Wyoming for his guidance during the elemental and isotopic analyses of the samples.

\section{REFERENCES}

Aber JD, McDowell W, Nadelhoffer KJ, Magill A. Berntso GM, Kamakea M, McNulty S, Currie W, Rustad L, Fernandez I. 1998. Nitrogen saturation in temperate forest ecosystems - hypothesis revisited. Bioscience 48:921-934.

Aber JD, Nadelhoffer KJ, Steudler P, Melillo JM. 1989. Nitrogen saturation in northern forest ecosystems. Bioscience 39, 378-386.

Ariz, I, Cristina C, Moran JF, González-Moro MB, García-Olaverri C, González-Murua C, Martins-Loução MA, Aparicio-Trejo PM. 2011. Depletion of the heaviest stable N 

isotope is associated with $\mathrm{NH}_{4}{ }^{+} / \mathrm{NH}_{3}$ toxicity in $\mathrm{NH}_{4}{ }^{+}$-fed plants. BMC Plant Biology 2011 11:83.

Arróniz-Crespo M, Leake JR, Horton P, Phoenix GK. 2008. Bryophyte physiological responses to, and recovery from, long-term nitrogen deposition and phosphorus fertilization in acidic grassland. New Phytologist 180:864-74.

Asner GP, Seastedt TR, Townsend AR. 1997. The decoupling of terrestrial carbon and nitrogen cycles. Bioscience 47:226-234.

Austin AT, Bustamante MMC, Nardoto GB, Mitre SK, Pérez T, Ometto JPHB, Ascarrunz NL, Forti MC, Longo K, Gavito ME, Enrich-Prast A, Martinelli LA. 2013. Latin America's Nitrogen Challenge. Science 340:149.

Baker NR. 2008. Chlorophyll Fluorescence: a probe of photosynthesis in vivo. Annual Review of Plant Biology 59:89-113.

Barman p, Rajni K, Naik SK, Upadhyaya RC. 2004. Effect of nitrogen, phosphorus and potassium on growth and flowering of Cimbidiu. Journal of ornamental horticulture. 7:235-238.

Bauer GA, Bazzaz FA, Minocha R, Long S, Magill A, Aber J, Berntson GM. 2004. Effects of chronic $\mathrm{N}$ additions on tissue chemistry, photosynthetic capacity, and carbon sequestration potential of a red pine (Pinus resinosa Ait.) stand in the NE United States. Forest Ecology and Management. 196:173-186.

Baxter R, Emes MJ, Lee JA. 1992. Effects of an experimentally applied increase in ammonium on growth and amino-acid metabolism of Sphagnum cuspidatum Ehrh. ex. Hoffm. from differently polluted areas. New Phytologist 120:265-274.

Bichsel RB, Starman W, Yin-Tung W. 2008. Nitrogen, Phosphorus, and Potassium Requirements for Optimizing Growth and Flowering of the Nobile Dendrobium as a Potted Orchid. HortScience. 43:328-332.

Bobbink R, Hicks K, Galloway J, Spranger T, Alkemade R, Ashmore M, Bustamante M, Cinderby S, Davidson E, Dentener F, Emmett B, Erisman JW, Fenn M, Gilliam F, Nordin A, Pardo L, De Vries W. 2010. Global assessment of nitrogen deposition effects on terrestrial plant diversity: a synthesis. Ecological Applications 20:30-59. Britto T, Kronzucker H. 2002. $\mathrm{NH}_{4}{ }^{+}$toxicity in higher plants: a critical review. Journal of Plant Physiology 159:567-584. 
Brown KR, Thompson WA, Camm EL, Hawkins BJ, Guy RD. 1996. Effects of N addition rates on the productivity of Picea Sitchensis, Thuja plicata, and Tsuga heterophylla seedlings: II. Photosynthesis, ${ }^{13} \mathrm{C}$ discrimination and $\mathrm{N}$ partitioning in foliage. Trees 10:198-205

Calatayud A, Gorbe E, Roca D, Martínez PF. 2008. Effect of two nutrient solution temperatures on nitrate uptake, nitrate reductase activity, $\mathrm{NH}_{4}{ }^{+}$concentration and chlorophyll a fluorescence in rose plants. Environmental and Experimental Botany 64:65-74.

Díaz-Álvarez EA, Lindig-Cisneros R, Reyes-García C, de la Barrera E. 2014. Effects of simulated nitrogen deposition and a stable isotopic assessment for the neotropical epiphytic orchid Laelia speciosa. PeerJ PrePrint 2:e771v1.

Drennan PM. 2009. Temperature influences on plant species of arid and semi-arid regions with emphasis on CAM succulents. In: de la Barrera E, Smith WK, eds. Perspectives in biophysical plant ecophysiology: a tribute to Park S. Nobel. México DF: Universidad Nacional Autonoma de México pp. 57-94.

Ehleringer JR, Osmond BO. 1989. Stable isotopes. In: Pearcy RW, Ehleringer JR, Mooney HA, Rundel PW. Eds. Plant physiological ecology. London: Chapman \& Hall.

Evans RD, Bloom AJ, Sukrapanna SS, Ehleringer JR. 1996. Nitrogen isotope composition of tomato (Lycopersicon esculentum Mill. cv. T-5) grown under ammonium or nitrate nutrition. Plant Cell and Environment 19:1317-1323.

Evans RD. 2001. Physiological mechanisms influencing plant nitrogen isotope composition. Trends in Plant Science. 6:121-126.

Evans JR. 1989. Photosynthesis and nitrogen relationships in leaves of $\mathrm{C}_{3}$ plants. Oecologia. 78:9-19.

Galloway JN, Townsend AR, Erisman JW, Bekunda M, Cai Z, Freney JR, Martinelli LA, Seitzinger SP, Sutton MA. 2008. Transformation of the nitrogen cycle: recent trends, questions, and potential solutions. Science 320:889-92.

Galloway JN, Dentener FJ, Capone DG, Boyer EW, Howarth RW, Seitzinger SP, Asner GP, Cleveland CC, Green PA, Holland EA, Karl DM, Michaels AF, Porter JH, Townsend AR, Vörösmarty CJ. 2004. Nitrogen cycles: past, present, and future. Biogeochemistry 70:153-226. 
Guidi L, Degl'Innocenti E. 2008. Ozone effects on high light-induced photoinhibition in Phaseolus vulgaris. Plant Science 174:590-596.

Halbinger F, Soto MA. 1997. Laelia speciosa (H.B.K.) Schltr. In: Hágsater E. Soto MA, Greenwood E, Dressler RL, Cribb PJ, Rzedowski J, Catling PM, Sheviak CJ, Chiang F, Eds. Laelias of México, Orquídea (Méx.). 15:133-142. México City, México.

Hoagland DR, Arnon DI. 1950. The culture method for growing plants without soil. California Agriculture Experimental Circle 347:1-32.

Högberg P, Högberg MN, Quist ME, Ekblad A, Näsholm T. 1999. Nitrogen isotope fractionation during nitrogen uptake by ectomycorrhizal and nonmycorrhizal Pinus sylvestris. New Phytologist 142:569-576.

Hogewoning SW, Harbinson J. 2007. Insights on the development, kinetics, and variation of photoinhibition using chlorophyll fluorescence imaging of a chilled, variegated leaf. Journal of Experimental Botany 58:453-463.

Kolb K, Evans R. 2003. Influence of nitrogen source and concentration on nitrogen isotopic discrimination in two barley genotypes (Hordeum vulgare L.). Plant Cell and Environment. 26:1431-1440.

Le Bauer DS, Treseder KK, 2008. Nitrogen limitation of net primary productivity in terrestrial ecosystems is globally distributed. Ecology 89:371-79.

Lichtenthaler HK, AcA, Marek MV, Kalina J, Urban O. 2007. Differences in pigment composition, photosynthetic rates and chlorophyll fluorescence images of sun and shade leaves of four tree species. Plant Physiology. Biochemistry 45:577-588.

Lichtenthaler HK. 1987. Chlorophylls and carotenoids: pigments of photosynthetic membranes. Methods in Enzymology 148:350-382.

Lin Y, Duan L, Yang YS, Zhao DW, Zhang DB, Hao JM. 2007. Contribution of simulated nitrogen deposition to forest soil acidification in area with high sulfur deposition. Environmental Science 28:640-646.

Magalhaes JR, Huber DM, Tsai CY. 1992. Evidence of increased ${ }^{15} \mathrm{~N}$ ammonium assimilation in tomato plants with exogenous a-ketoglutarate. Plant Science 85:135-141.

Majerowicz N, Kerbauy GB, Nievola CC, Suzuki RM. 2000. Growth and nitrogen metabolism of Catasetum fimbriatum (Orchidaceae) grown with different nitrogen sources. Environmental and Experimental Botany 44:195-206. 
Mangosá TJ, Berger RG. 1997. Determination of major chlorophyll degradation products. European Food Research and Technology 204:345-350.

Maniruzzaman M, Asaeda T. 2012. Fractionation of Stable Isotopes of Nitrogen in Trapa japonica During Uptake of $\mathrm{NH}_{4}{ }^{+}-\mathrm{N}$. Research in Plant Biology 2:48-52.

Massacci A, Nabiev SM, Pietrosanti L, Nematov SK, Chernikova TN, Thor K, Leipner J. 2008. Response of the photosynthetic apparatus of cotton (Gossypium hirsutum) to the onset of drought stress under oak forest conditions studied by gas exchange analysis and chlorophyll fluorescence imaging. Plant Physiology Biochemistry 46:189-195.

Maxwell K, Johnson G. 2000. Chlorophyll fluorescence -a practical guide. Journal of Experimental Botany 51:659-668.

Mondragó D, Valverde T, Hernández-Apolinar M. 2015. Population ecology of epiphytic angiosperms: A review. Tropical Ecology. 56:01-39.

Nakaji·T, Fukami M, Dokiya Y, Izuta T. 2001. Effects of high nitrogen load on growth, photosynthesis and nutrient status of Cryptomeria japonica and Pinus densiflora seedlings. Trees 15:453-461.

Nobel PS. 1999. Physicochemical and Environmental Plant Physiology, second Ed. Academic Press, San Diego California.

Nobel PS, de la Barrera E. 2002. Nitrogen Relations for net $\mathrm{CO}_{2}$ uptake by the cultivated hemiepiphytic cactus, Hylocerus undatus. Scientia Horticulturae 96:281-292.

O'Deen WA. 1989 Wheat volatilized ammonia and resulting nitrogen isotopic fractionation. Agronomy Journal. 81:980-985.

Phoenix GK, Hicks WK, Cinderby S, Kuylenstierna CI, Stock WD, Dentener FJ, Giller KE, Austin AT, Lefroy DB, Gimeno BS, Ashmore MR, Ineson P. 2006. Atmospheric nitrogen deposition in world biodiversity hotspots: the need for a greater global perspective in Assessing N deposition impacts. Global Change Biology 12:470-476.

Poorter HN. 2000. The role of biomass allocation in the growth response of plants to different level of light, $\mathrm{CO}_{2}$, nutrients and water: a quantitative review. Australian Journal of Plant Physiology 27:597-607.

Raven JA, Farquhar GD. 1990. The influence of $\mathrm{N}$ metabolism and organic acid synthesis on the natural abundance of isotopes of carbon in plants. New Phytologist 116:505-529. 
Rehfeldt GE, Crookston NL, Sáenz-Romero C, Campbell EM. 2012. North American vegetation model for land-use planning in a changing climate: a solution to large classification problems. Ecological Applications. 22:119-141.

Sala OE, Chapin III SF, Armesto JJ, Berlow E, Bloomfield J, Dirzo R, Huber-Sanwald E, Huenneke LF, Jackson RB, Kinzig A, Leemans R, Lodge DM, Mooney HA, Oesterheld M, Poff NL, Sykes MT, Walker BH, Walker M, Wal DH. 2000. Global Biodiversity Scenarios for the Year 2100. Science 287:1770-1774.

Sánchez E, Soto J, García PC, López-Lefebre L, Rivero R, Ruíz JM, Romero L. 2000. Phenolic compounds and oxidative metabolism in green vean plants under nitrogen toxicity. Australian Journal of Plant Physiology 27:973-978.

Secretaria del Medio Ambiente del Gobierno del Distrito Federal 2012. Calidad del aire en la Ciudad de México Informe 2011. Creative Commons, México, 164 pp.

Soto-Arenas M. 1994. Population studies in Mexican orchids. In: Pridgeon AM. Ed. Proceedings of the $14^{\text {th }}$ World Orchid Conference. Glasgow: HMSO Publ.

Soto-Arenas MA, Solano-Gómez AR. 2007. Ficha técnica de Laelia speciosa. In: SotoArenas MA. Ed. Información actualizada sobre las especies de orquideas del PROYNOM-059-ECOL-2000. México. D.F. Instituto Chinoin A.C., Herbario de la Asociación Mexicana de Orquideología A.C. Bases de datos SNIB-CONABIO. Proyecto No. W029.

Stuart Chapin III F, Zavaleta ES, Eviner VT, Naylor RL, Vitousek PM, Reynolds HL, Hooper DU, Lavorel S, Sala OE, Hobbie SE, Mack MC, Díaz S. 2000. Consequences of changing biodiversity. Nature 405:234-242.

Templer PH, Pinder RW, Goodale CL. 2012. Effects of nitrogen deposition on greenhousegas fluxes for forests and grasslands of North America. Frontiers in Ecology and Environment 10:547-553.

Vargas-Tapia P, Castellanos-Ramos JZ, Muñoz-Ramos JJ, Sánchez-García P, TijerinaChávez L, López-Romero RM, Martínez-Sánchez C, Ojodeagua-Arredondo JL. 2008. Effect of particle size on some physical properties of tezontle (volcanic rock) from the State of Guanajuato. Agricultura técnica en México 34:323-331.

Villers-Ruiz L. and Trejo-Vazquez I. 2000. El cambio climático y la vegetación en México. In: García C, ed. México: una visión hacia el siglo XXI. El cambio climático en 
México. Instituto Nacional de Ecología, Universidad Nacional Autónoma de México, US Country Studies Program, México, 57-66.

Vitousek PM. 1994. Beyond global warming: ecology and global chance. Ecology 75:18611876

Wortman E, Tomaszewski T, Waldner P, Schleppi P, Thimonier A, Eugster W, Buchmann N, Sievering H. 2012. Atmospheric nitrogen deposition and canopy retention influences on photosynthetic performance at two high nitrogen deposition Swiss forests. Tellus B. 64:17216.

Yanez-Ocampo G, Sanchez-Salinas E, Jimenez-Tobonb GA, Michel Penninckx M, OrtizHernández ML. 2009. Removal of two organophosphate pesticides by a bacterial consortium immobilized in alginate or tezontle. Journal of Hazardous Materials 168:1554-1561.

Ying-Chun L, Hou-Bao F, Yan-Yan L, Wen-Fei L, Ying-Hong Y. 2010. Effects of simulated nitrogen deposition on growth and photosynthesis of 1-year-old Chinese fir (Cunninghamia lanceolata) seedlings. Acta Ecologica Sinica 30:150-154.

Yoneyama T, Omata T, Nakata S, Yazaki J. 1991. Fractionation of Nitrogen Isotopes during the Uptake and Assimilation of Ammonia by Plants. Plant Cell Physiology 32:12111217.

Yoneyama T, Matsumaru T, Usui K, Engelaar WMHG. 2001. Discrimination of nitrogen isotopes, during absorption of ammonium and nitrate at different nitrogen concentrations by rice (Oryza sativa L.) plants. Plant Cell and Environment. 24:133139.

Zotz G, Asshoff R. 2010. Growth in epiphytic bromeliads: response to the relative supply of phosphorus and nitrogen. Plant Biology 12: 108-113

Zotz G, Bogusch W, Hiezt P, Ketteler N. 2010. Growht of epiphytic bromeliads in a changing world: the effects of $\mathrm{CO}_{2}$, water and nutrient supply. Acta Oecologica 36:659-665. 


\section{Table $\mathbf{1}$ (on next page)}

Statistical analyses

Kruskal-Wallis one-way ANOVA and parametric one-way ANOVA for the responses of Laelia speciosa individuals growing in a shadehouse under various rates of simulated nitrogen deposition. 
2 Table 1. Kruskal-Wallis one-way ANOVA and parametric one-way ANOVA for the

3 responses of Laelia speciosa individuals growing in a shadehouse under various rates of

4 simulated nitrogen deposition.

5

6

7

8

9

10

11

12

13

14

15

16

17

18

19

20 
1

Organ production

Number of new leaves (open bars), pseudobulbs (right hatched bars) and flowers (left hatched bars) that developed on plants of Laelia speciosa that were watered with different doses of nitrogen. Data are shown as mean \pm S.E ( $n=20$ plants per dose of nitrogen). Different letters indicate significant differences $(p<0.05)$ for organs.

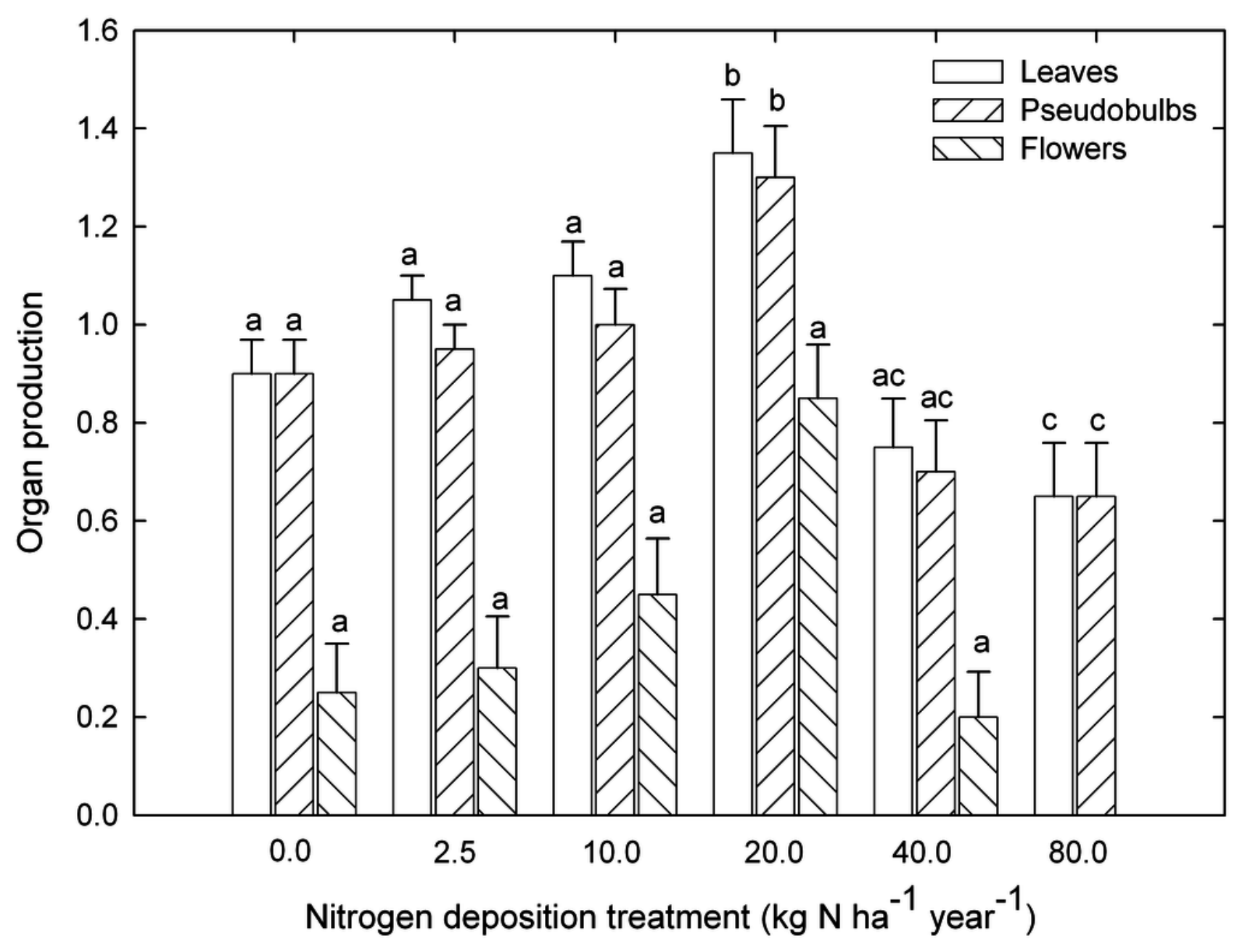


2

Ecophysiological responses for leaves of $L$. speciosa to simulated nitrogen deposition.

Number of new leaves (open bars), pseudobulbs (right hatched bars) and flowers (left hatched bars) that developed on plants of Laelia speciosa that were watered with different doses of nitrogen. Data are shown as mean \pm S.E ( $n=20$ plants per dose of nitrogen). Different letters indicate significant differences $(p<0.05)$ for organs. 


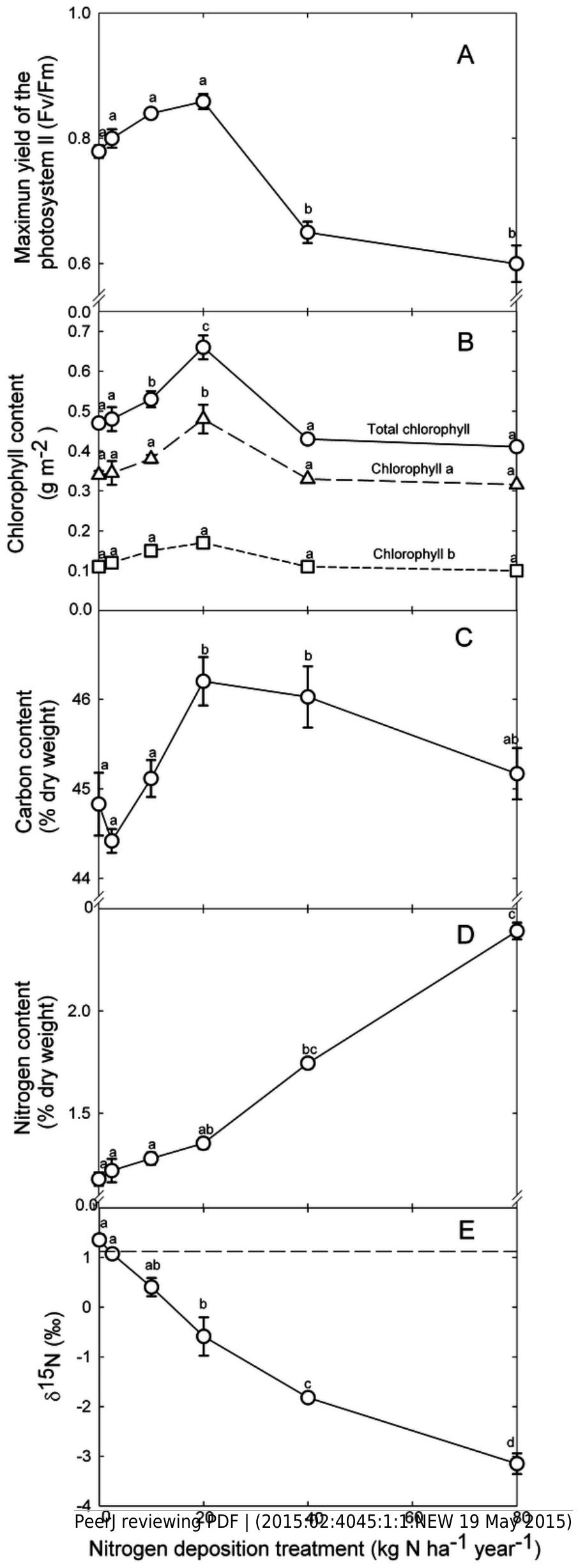

